\title{
Abscisic acid induced changes in cell wall peroxidase activity and hydrogen peroxide level in roots of rice seedlings
}

\author{
Chuan Chi Lin, Ching Huei Kao* \\ Department of Agronomy, National Taiwan University, Taipei, Taiwan, PR China \\ Received 5 June 2000; received in revised form 19 September 2000; accepted 19 September 2000
}

\begin{abstract}
The changes in the activity of peroxidase (POD) extracted from the cell wall and the level of $\mathrm{H}_{2} \mathrm{O}_{2}$ of rice seedling roots treated with abscisic acid (ABA) and their correlation with root growth were investigated. Increasing concentrations of ABA from 3 to $18 \mu \mathrm{M}$ progressively reduce root growth and increase POD activities (using guaiacol or ferulic acid as a substrate) extracted from the cell wall of rice roots. The reduction of root growth by ABA is also correlated with an increase in $\mathrm{H}_{2} \mathrm{O}_{2}$ level. Both diamine oxidase (DAO) and NADH peroxidase (NADH-POD) are known to be responsible for the generation of $\mathrm{H}_{2} \mathrm{O}_{2}$. ABA treatment increased NADH-POD and DAO activities in roots of rice seedlings, suggesting that NADH-POD and DAO contribute to the generation of $\mathrm{H}_{2} \mathrm{O}_{2}$ in the cell wall of ABA-treated roots. An increase in the level of $\mathrm{H}_{2} \mathrm{O}_{2}$ and the activity of POD extracted from the cell wall of rice roots preceded root growth reduction caused by ABA. An increase in DAO and NADH-POD activities coincided with an increase in $\mathrm{H}_{2} \mathrm{O}_{2}$ in roots caused by ABA. Since DAO catalyzes the oxidation of putrescine, the results that $\mathrm{ABA}$ increases the activity of DAO in roots is consistent with those that ABA decreases the level of putrescine. In conclusion, cell wall stiffening catalyzed by POD is possibly involved in the regulation of root growth reduction caused by ABA. (C) 2001 Elsevier Science Ireland Ltd. All rights reserved.
\end{abstract}

Keywords: Abscisic acid; Diamine oxidase; $\mathrm{H}_{2} \mathrm{O}_{2}$; Oryza sativa; Peroxidase; Root growth

\section{Introduction}

It has been suggested that growth reduction is likely to result from cell wall stiffening processes related to formation of cross-links among cell wall polymers [1]. The formation of cross-links between cell wall components is mediated by cell wall-associated peroxidase (POD) enzymes [1]. There are many reports showing that POD activity extracted from cell walls is inversely related to cell growth [2-8]. With the aid of specific antibodies for POD it was shown that hypocotyl growth could be enhanced in the presence of the antibodies, or

Abbreviations: DAO, Diamine oxidase; DW, Dry weight; FPOD, Ferulic acid peroxidase; FW, Fresh weight; POD, Peroxidase; Put, Putrescine; Spd, Spermidine; Spm, Spermidine.

* Corresponding author. Tel.: + 886-2-23698159; fax: + 886-223620879 .

E-mail address: kaoch@ccms.ntu.edu.tw (C.H. Kao). alternatively, with additional POD the growth was stunted [9].

Abscisic acid (ABA) is ubiquitous in higher plants and has many physiological effects on the growth and differentiation of plants [10]. It is usually accepted that ABA is a potent growth inhibitor, although in a few cases it may promote growth [11]. It has been shown that ABA is required for maize primary root elongation at low water potentials $[12,13]$. However, the mechanism underlying the inhibition of plant growth by ABA is not yet clear. Zocchi and De Nisi [14] reported that ABA inhibited elongation of the maize coleoptile and reduced proton extrusion. We have previously reported that an increase in ionically bound POD (removable from homogenized tissue with high ionic strength buffer) activity is associated with growth inhibition of rice seedling roots caused by ABA [15]. $\mathrm{H}_{2} \mathrm{O}_{2}$ is a necessary substrate 
for cell wall stiffening process catalyzed by POD $[5,16]$. Using a sensitive tissue-print assay, Schopfer [17] has been able to demonstrate that $\mathrm{H}_{2} \mathrm{O}_{2}$ is localized in the cell wall of pea epicotyl. The formation of $\mathrm{H}_{2} \mathrm{O}_{2}$ by isolated cell wall from horseradish has been reported [18]. It has been shown that $\mathrm{H}_{2} \mathrm{O}_{2}$ inhibits auxin-mediated growth of maize coleoptile segments [16] and $\mathrm{H}_{2} \mathrm{O}_{2}$ causes a rapid cross-links of cell wall polymers [16,19]. Therefore, to ensure complete stiffening of the cell wall a sufficient supply of $\mathrm{H}_{2} \mathrm{O}_{2}$ is required. The present investigation was designed to study the changes in POD activity extracted from the cell wall and $\mathrm{H}_{2} \mathrm{O}_{2}$ level in roots of ABA-treated rice seedlings and their correlation with root growth.

\section{Materials and methods}

Rice (Oryza sativa L., cv. Taichung Native 1) seeds were sterilized with $2.5 \%$ sodium hypochlorite for $15 \mathrm{~min}$ and washed extensively with distilled water. These seeds were then germinated in Petri dish $(20 \mathrm{~cm})$ containing distilled water at $37^{\circ} \mathrm{C}$ under dark condition. After 1 day incubation, uniformly germinated seeds were selected and transferred to Petri dishes $(9.0 \mathrm{~cm})$ containing two sheets of Whatman No. 1 filter paper moistened with $10 \mathrm{ml}$ of distilled water or test solutions. Each Petri dish contained 20 germinated seeds. Each treatment was replicated 4 times. The germinated seeds were allowed to grow at $27^{\circ} \mathrm{C}$ in darkness. To avoid the loss by evaporation and uptake by the seeds, a further $3 \mathrm{ml}$ of distilled water or test solutions was added to each Petri dish on day 3.

Cell walls were prepared by homogenizing roots in ice-cold phosphate buffer $(50 \mathrm{mM}, \mathrm{pH} 5.8)$ using a pestle and mortar. The homogenate was centrifuged at $1000 \times g$, and washed at least four times with $50 \mathrm{mM}$ phosphate buffer [6]. The pellet was collected and used as a cell wall fraction.

POD ionically bound to the cell wall was extracted with $1 \mathrm{M} \mathrm{NaCl}$. Cell walls were prepared as described above were incubated in $1 \mathrm{M} \mathrm{NaCl}$ for $2 \mathrm{~h}$ with shaking at $30^{\circ} \mathrm{C}$ and centrifuged at $1000 \times g$. The supernatant was used for enzyme assays. Guaiacol was used as substrate to determine cell wall POD. The assay medium contained $0.05 \mathrm{M}$ phosphate buffer ( $\mathrm{pH} 5.8$ ), $7.2 \mathrm{mM}$ guaiacol, $11.8 \mathrm{mM} \mathrm{H}_{2} \mathrm{O}_{2}$ and $0.1 \mathrm{ml}$ enzyme extract in a final assay volume of $3.0 \mathrm{ml}$. The reaction was initiated by the addition of $\mathrm{H}_{2} \mathrm{O}_{2}$ and the change in absorbance at $470 \mathrm{~nm}$ was measured [20]. Activity was calculated using the extinction coefficient (26.6 $\mathrm{mM}^{-1} \mathrm{~cm}^{-1}$ at $470 \mathrm{~nm}$ ) for tetraguaiacol [20]. One unit of cell wall POD was defined as the amount of enzyme that causes the formation of 1 $\mu$ mol tetraguaiacol per min. Ferulic acid POD (FPOD) was assayed according to Sanchez et al. [21]. The oxidation of ferulic acid was measured spectrophotometrically following the absorance decrease at $310 \mathrm{~nm}$ in a reaction mixture containing $1.35 \mathrm{ml} \mathrm{Na}$-phosphate buffer $(0.2 \mathrm{M}, \mathrm{pH} 5.8)$, $0.5 \mathrm{ml}$ ferulic acid $(240 \mu \mathrm{M}), 0.5 \mathrm{ml} \mathrm{H}_{2} \mathrm{O}_{2}(3 \mathrm{mM})$ and $0.15 \mathrm{ml}$ enzyme extract. One unit of FPOD was defined as a decrease of $1 A_{310} \mathrm{~min}^{-1}$.

NADH-POD, which catalyzes the reduction of $\mathrm{O}_{2}$ to $\mathrm{H}_{2} \mathrm{O}_{2}$ using NADH as electron donor, activities in the ionic cell wall fraction were determined according to the method of Ishida et al. [22]. The assay mixture contained $50 \mu \mathrm{M}$ NADH in Na-acetate buffer ( $30 \mathrm{mM}, \mathrm{pH} 6.5), 5 \mathrm{mM} \mathrm{MnCl}_{2}$ and 20 $\mu \mathrm{M} p$-coumaric acid. The reaction was started by adding the enzyme, and the decrease of absorbance at $340 \mathrm{~nm}$ by oxidizing NADH was measured at $25^{\circ} \mathrm{C}$. One unit of NADH-POD was defined as a decrease of $1 A_{340} \mathrm{~min}^{-1}$.

DAO activities in the ionic cell wall fraction were measured by the method of Naik et al. [23]. The reaction mixture contained $50 \mathrm{mM}$ phosphate buffer (pH 7.8), $10 \mathrm{mM}$ putrescine (Put), $0.1 \mathrm{mM}$ pyridoxal phosphate and enzyme extract in a total volume of $4 \mathrm{ml}$. After incubation at $30^{\circ} \mathrm{C}$ for $1 \mathrm{~h}$ the reaction was terminated using $1 \mathrm{ml} \mathrm{20 \% (w/v)}$ trichloroacetic acid. After $30 \mathrm{~min}$, the incubation mixture was centrifuged at $5000 \times g$ for $15 \mathrm{~min}$. One $\mathrm{ml}$ of ninhydrin mixture $(250 \mathrm{mg}$ ninhydrin in $6 \mathrm{ml}$ acetic acid and $4 \mathrm{ml}$ phosphoric acid) was added to the supernatant. Colour was developed at $100^{\circ} \mathrm{C}$ for $30 \mathrm{~min}$. After adding $1 \mathrm{ml}$ of acetic acid absorbance was measured at $510 \mathrm{~nm}$. In controls, trichloroacetic acid added prior to the enzyme solution. One unit of DAO was defined as an increase of $1 A_{510}$ per h.

The $\mathrm{H}_{2} \mathrm{O}_{2}$ level was colorimetrically measured as described by Jana and Choudhuri [24]. $\mathrm{H}_{2} \mathrm{O}_{2}$ was extracted by homogenizing 10 roots with $3 \mathrm{ml}$ of phosphate buffer (50 mM, pH 6.8) containing catalase inhibitor hydroxylamine $(1 \mathrm{mM})$. The homogenate was centrifuged at $6000 \times g$ for $25 \mathrm{~min}$. To determine $\mathrm{H}_{2} \mathrm{O}_{2}$ levels, $3 \mathrm{ml}$ of extracted solution was mixed with $1 \mathrm{ml}$ of $0.1 \%$ titanium sulfate 
in $20 \%(\mathrm{v} / \mathrm{v}) \mathrm{H}_{2} \mathrm{SO}_{4}$ and the mixture was then centrifuged at $6000 \times g$ for $15 \mathrm{~min}$. The intensity of the yellow colour of the supernatant was measured at $410 \mathrm{~nm} . \mathrm{H}_{2} \mathrm{O}_{2}$ level was calculated using the extinction coefficient $0.28 \mu \mathrm{mol}^{-1} \mathrm{~cm}^{-1}$.

Proline was extracted and its concentration determined by the method of Bates et al. [25]. Roots were homogenized with 3\% sulfosalicylic acid and the homogenate was centrifuged. The supernatant was treated with acetic acid and acid ninhydrin, boiled for $1 \mathrm{~h}$ and then absorbance at $520 \mathrm{~nm}$ was determined. Proline level was calculated using the extinction coefficient $3.24 \mu_{\mathrm{mol}}^{-1} \mathrm{~cm}^{-1}$. Ammonium was extracted by homogenizing roots in 0.3 $\mathrm{mM}$ sulphuric acid ( $\mathrm{pH} 3.5)$. The homogenate was centrifuged for $10 \mathrm{~min}$ at $39000 \times \mathrm{g}$, and the supernatant was used for determination of ammonium as described by Lin and Kao [26].

For determinations of Put, spermidine (Spd) and spermine $(\mathrm{Spm})$, roots were homogenized in $5 \%(\mathrm{v} / \mathrm{v})$ perchloric acid. Levels of Put, Spd and Spm were determined using HPLC after benzolation as described previously [27].

For all measurements, each treatment was repeated four times. All experiments described here were repeated at least three times. Similar results and identical trends were obtained each time. The data reported here are from a single experiment.

\section{Results and discussion}

Root growth was followed by measuring FW and DW of roots. Fig. 1 shows the effect of ABA on root growth of rice seedlings. Increasing concentrations of ABA from 3 to $18 \mu \mathrm{M}$ progressively decrease root growth. The reduction of root growth with increasing ABA concentrations is correlated with an increase in cell-wall POD activity. Although there are some reports indicating that ABA may promote root growth [11-13], the results of the present investigation are consistent with the generally accepted idea that ABA is a potent root growth inhibitor.

A key role of cell-wall POD in the stiffening of the cell wall through formation of cross-links between wall polymers and consequently, in the reduction or cessation of cell growth has been proposed [1]. Guaiacol was used as a substrate for cell-wall POD reported in Fig. 1. However, guaiacol is not the natural substrate in the formation of cross-links between wall polymer. The polysaccharides of plant cell wall contain hydroxycinnamic acids that are presented as an ester-linked side chain. Ferulic acid has been identified as being ester linked to arabinoxylans in cell walls of monocotyledonous plants [28,29]. A key role in the cell-wall stiffening of dimerization of ferulic acid catalyzed by cell-wall POD has been proposed [21]. Although we do not know the constituents of polysaccharides of the cell wall in rice seedling roots, it is most likely that ferulic acid is also present in the cell wall of rice roots used in the present investigation. If this is indeed the case, then ABA is expected to increase the POD activity against ferulic acid (ferulic acid peroxidase or
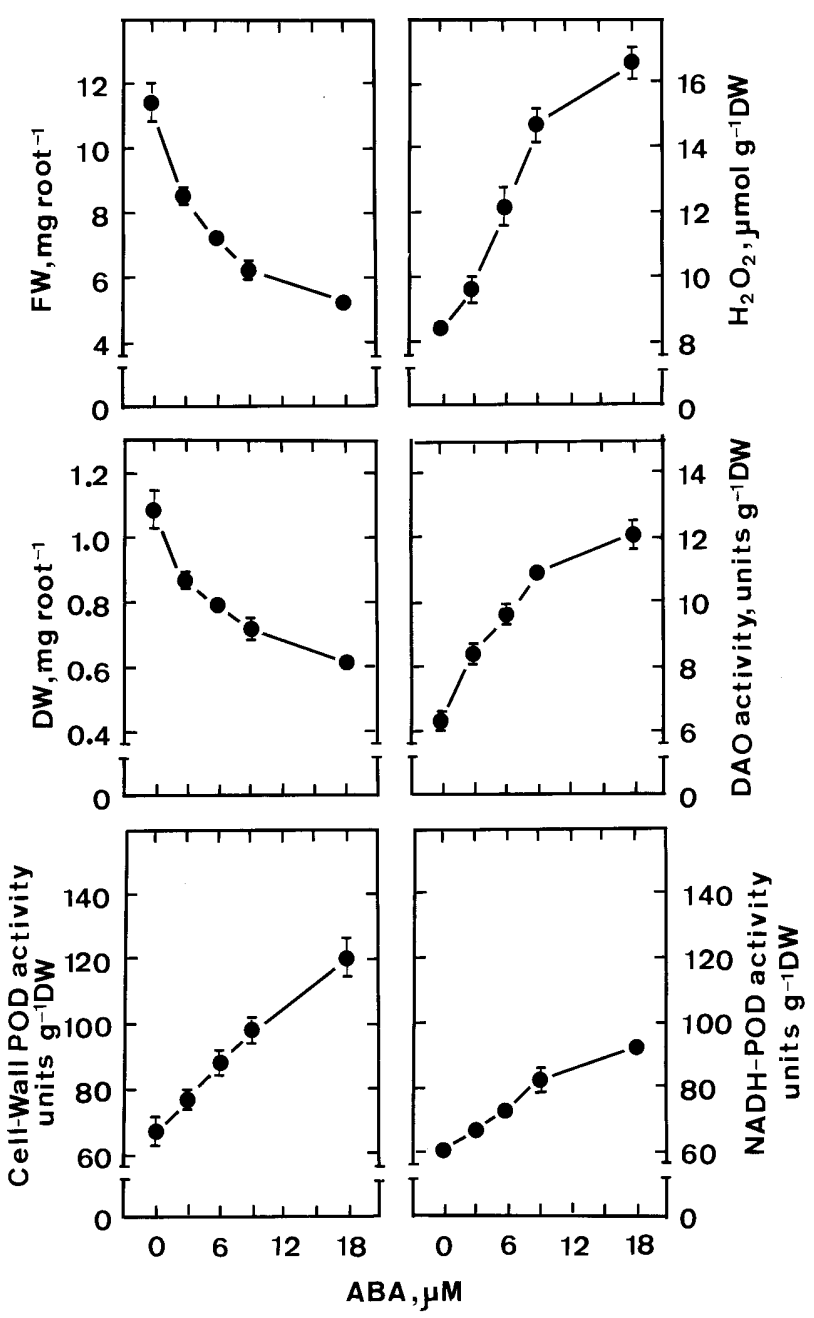

Fig. 1. Effects of ABA on root growth, cell wall POD activities, $\mathrm{H}_{2} \mathrm{O}_{2}$ levels, diamine oxidase (DAO) activities and NADH peroxidase (NADH-POD) activities in roots of rice seedlings. Root growth, $\mathrm{H}_{2} \mathrm{O}_{2}$ levels and enzyme activities were determined after 5 days of treatment. Vertical bars represent standard errors $(n=4)$. 


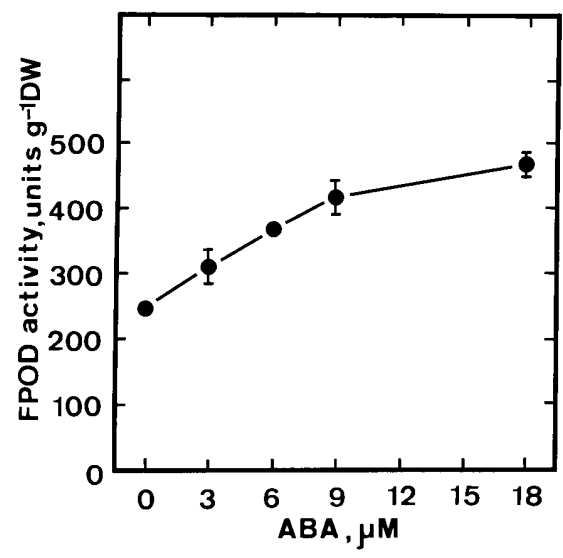

Fig. 2. Effects of ABA on ferulic acid peroxidase (FPOD) activities in roots of rice seedlings. FPOD activities were determined after 5 days of treatment. Vertical bars represent standard errors $(n=4)$.

FPOD). Fig. 2 shows that the reduction of root growth with increasing ABA concentrations is correlated with an increase in FPOD activity.

The results reported in the Figs. 1 and 2 seem to suggest that ABA-induced inhibition in root growth of rice seedlings is due to cell-wall stiffening process catalyzed by POD. $\mathrm{H}_{2} \mathrm{O}_{2}$ is a necessary substrate for POD $[1,5,16] . \mathrm{H}_{2} \mathrm{O}_{2}$ has been demonstrated to cause a rapid cross-links of cell wall polymers $[5,16,19]$. If POD regulates cell-wall stiffening by catalyzing the oxidative cross-linking of cell wall polymers, there must be a sufficient supply of $\mathrm{H}_{2} \mathrm{O}_{2}$. Thus, it is of great interest to know whether $\mathrm{ABA}$ increases the level of $\mathrm{H}_{2} \mathrm{O}_{2}$ in roots of rice seedlings. Fig. 1 shows that increasing concentration of ABA from 3 to $18 \mu \mathrm{M}$ progressively increased $\mathrm{H}_{2} \mathrm{O}_{2}$ levels in roots. Schopfer [17] reported that in the hypocotyl of sunflower and cucumber seedlings the light-mediated inhibition of elongation growth was correlated with a strong increase in $\mathrm{H}_{2} \mathrm{O}_{2}$ in the epidermis and in the vascular bundle. In a recent work, we demonstrated that exogenous application of $\mathrm{H}_{2} \mathrm{O}_{2}$ resulted in an inhibition of root growth of rice seedlings [30]. These results are in agreement with those of Schopfer [16] who demonstrated that $\mathrm{H}_{2} \mathrm{O}_{2}$ inhibited auxin-mediated growth of maize coleoptile segments [16]. Our results seem to suggest POD-mediated cell-wall stiffening of rice roots is involved in ABA-inhibited root growth.

One of potential sources of $\mathrm{H}_{2} \mathrm{O}_{2}$ in plant cells is cell wall- or membrane-bound NADH-POD are responsible for $\mathrm{H}_{2} \mathrm{O}_{2}$ generation [18,31]. As expected, increasing cell-wall NADH-POD activities were found to increase with increasing ABA concentrations in rice seedling roots (Fig. 1). Diamine oxidase (DAO), which is involved in polyamine catabolism, oxidizes Put with the formation of $\Delta^{1}$-pyrroline together with $\mathrm{H}_{2} \mathrm{O}_{2}$ and ammonia [32]. DAO activity is mainly localized in cell walls [33] and perhaps plays a role in regulating Put levels [32] or providing $\mathrm{H}_{2} \mathrm{O}_{2}$ required for peroxidation reactions that occur in the cell walls for the formation of cross-links [33]. It seems that DAO is another source leading to $\mathrm{H}_{2} \mathrm{O}_{2}$ generation in ABA-inhibited root growth of rice seedlings. To test this, we determined the activities of DAO in rice seedling roots in response to various concentrations of ABA (Fig. 1). As expected, increasing concentrations of ABA from 3 to $18 \mu \mathrm{M}$ progressively increased DAO activities. This result is consistent with the observations that ABA treatment decreases Put level but has no effect on Spd and Spm levels (Fig. 3).

It is known that ammonium strongly inhibits the growth of many plants [34]. Exogenous application of $\mathrm{NH}_{4} \mathrm{Cl}$ was also found to reduce root growth [26] and to increase ionically bound POD

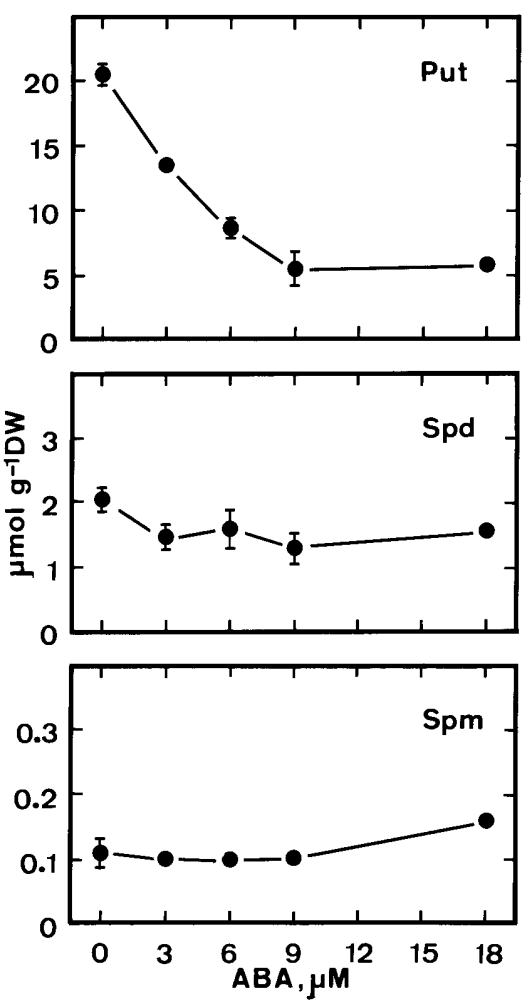

Fig. 3. Effects of ABA on the levels of polyamines in roots of rice seedlings. Putrescine (Put), spermidine (Spd) and spermine $(\mathrm{Spm})$ were determined after 5 days of treatment. Vertical bars represent standard errors $(n=4)$. 


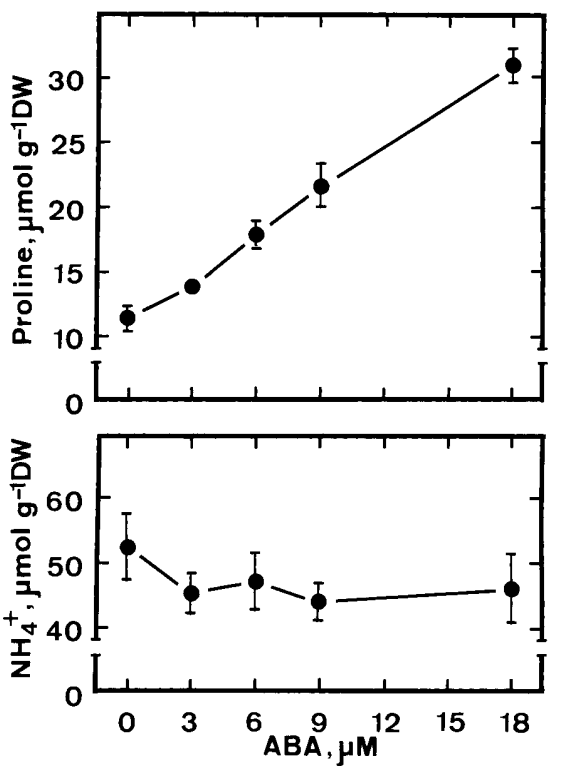

Fig. 4. Effects of ABA on the levels of proline and ammonium in roots of rice seedlings. Proline and ammonium were determined after 5 days of treatment. Vertical bars represent standard errors $(n=4)$.

activity [7] of rice seedlings. Previously, we also reported that exogenous application of proline resulted in an inhibition of root growth of rice seedlings and an increase in ionically bound POD [7]. Thus, it would be of great interest to understand whether ABA treatment resulted in an accumulation of proline and ammonium in roots of rice seedlings. Fig. 4 shows that $\mathrm{ABA}$ treatment increases proline level but had no effect on ammonium level. In our unpublished data, we have shown that exogenous proline application resulted in a reduction of root growth, an increase in $\mathrm{H}_{2} \mathrm{O}_{2}$ level, cell-wall POD and FPOD activities in roots of rice seedlings. The observations that rice seedlings fed with proline, which resulted in an increase in POD activity extracted from the cell wall and $\mathrm{H}_{2} \mathrm{O}_{2}$ level in roots, reduced root growth in the same way that ABA did, further support that cell-wall stiffening may be involved in the regulation of root growth reduction of rice seedlings exposed to ABA.

To test the causal relationship among root growth reduction, cell wall POD and FPOD activities, $\mathrm{H}_{2} \mathrm{O}_{2}$ level, and cell wall DAO and NADHPOD activities caused by ABA, 2-day-old seedlings were transferred to distilled water and ABA, respectively, for 4, 8, 12 and $16 \mathrm{~h}$. Changes in root growth, cell wall POD and FPOD activities, $\mathrm{H}_{2} \mathrm{O}_{2}$ level, and cell wall DAO and NADHPOD activities were then monitored. As indicated in Table 1, an increase in cell wall POD and FPOD activities and $\mathrm{H}_{2} \mathrm{O}_{2}$ level preceded inhibition of root growth caused by ABA. Clearly, the links between ABA treatment, cell wall POD and FPOD, $\mathrm{H}_{2} \mathrm{O}_{2}$ and root growth are well established. The observations that an increase in DAO and NADH-POD activities coincides with an increase in $\mathrm{H}_{2} \mathrm{O}_{2}$ level in roots caused by ABA (Table 1)

Table 1

Changes in root growth, cell wall POD activity, ferulic acid peroxidase (FPOD) activity, $\mathrm{H}_{2} \mathrm{O}_{2}$ level, diamine oxidase (DAO) activity and NADH peroxidase (NADH-POD) activity in roots of rice seedlings treated with $\mathrm{ABA}^{\mathrm{a}}$

\section{Time, hours}

$\begin{array}{lllll}0 & 4 & 8 & 12 & 16\end{array}$

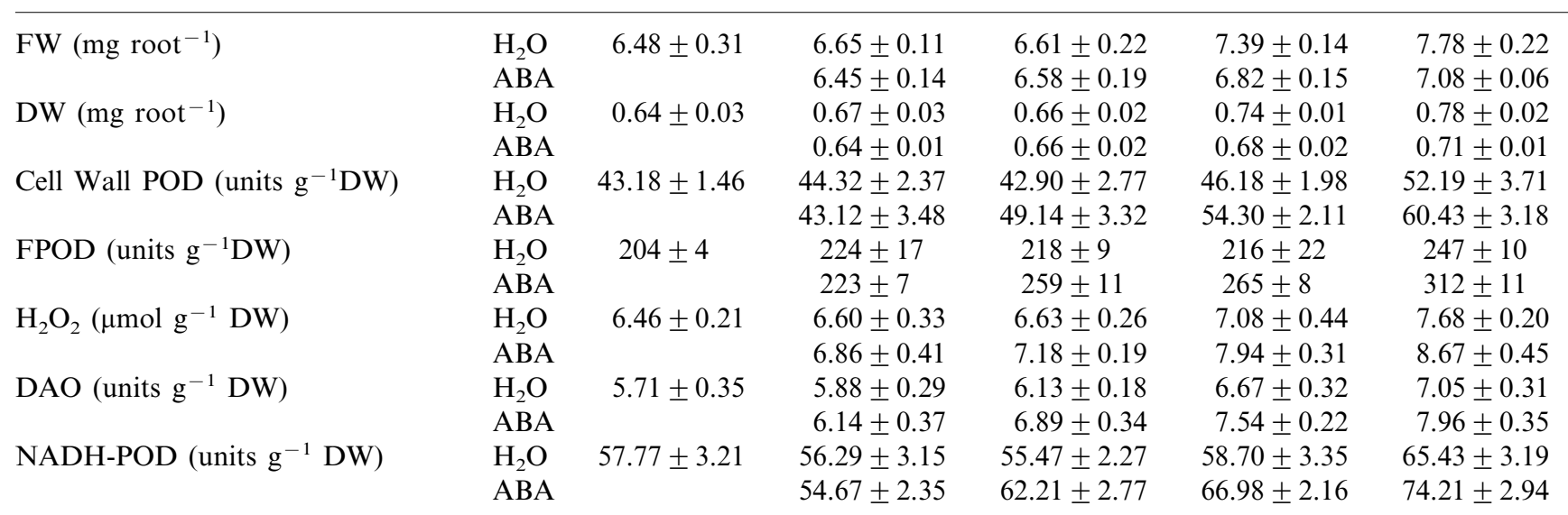

\footnotetext{
${ }^{\text {a }}$ Rice seeds were germinated in distilled water for 2 days and then transferred to distilled water and ABA (9 $\left.\mu \mathrm{M}\right)$, respectively.
} 
suggest that DAO and NADH-POD are the sources for the generation of $\mathrm{H}_{2} \mathrm{O}_{2}$ in the cell wall. NADH-POD catalyzes the reduction of $\mathrm{O}_{2}$ to $\mathrm{H}_{2} \mathrm{O}_{2}$ using NADH. The question now arises by which mechanism NADH is provided. Gross [31] provided evidence to show that cell wall-bound malate dehydrogenase was involved in the production of NADH. However, we have not succeeded in detecting cell wall-bound malate dehydrogenase in roots of rice seedlings. Frahry and Schopfer [35] also failed to detect cell wall-bound malate dehydrogenase activity in soybean roots. It seems that NADH-POD plays minor role, if any, in providing $\mathrm{H}_{2} \mathrm{O}_{2}$ in ABA-treated roots of rice seedlings. Since $\mathrm{H}_{2} \mathrm{O}_{2}$ can rapidly pass from the cytoplasm to the cell wall [36], a cytoplasmic origin of released $\mathrm{H}_{2} \mathrm{O}_{2}$ cannot be ruled out.

In conclusion, the data reported in the present investigation support the involvement of cell-wall stiffening in growth reduction in rice seedling roots exposed to ABA.

\section{Acknowledgements}

This work was supported by the National Science Council of the Republic of China (NSC 89-2313-B-002-009).

\section{References}

[1] S.C. Fry, Cross-linking of matrix polymers in the growing cells of angiosperms, Annu. Rev. Plant Physiol. 37 (1986) 165-186.

[2] M.A. Bacon, D.S. Thompson, W.J. Davies, Can cell wall peroxidase activity explain the leaf growth response of Lolium temulentum L. during drought?, J. Exp. Bot. 48 (1997) 2075-2085.

[3] S.L. Chen, C.H. Kao, Cd induced changes in proline level and peroxidase activity in roots of rice seedlings, Plant Growth Regul. 17 (1995) 67-71.

[4] R. Goldberg, M. Liberman, C. Mathieu, M. Pierron, A.M. Catesson, Development of epidermal cell wall peroxidases along the mung been hypocotyl: possible involvement in the cell wall stiffening process, J. Exp. Bot. 193 (1987) 1378-1390.

[5] M. Hohl, H. Greiner, P. Schopfer, The cryptic growth response of maize coleoptile and its relationship to $\mathrm{H}_{2} \mathrm{O}_{2}$-dependent cell wall stiffening, Physiol. Plant 94 (1995) 491-498.

[6] T.-M. Lee, Y.-H. Lin, Changes in soluble and cell wall-bound peroxidase activities with growth in anoxiatreated rice (Oryza sativa L.) coleoptiles and roots, Plant Sci. 106 (1995) 1-7.
[7] C.C. Lin, C.H. Kao, $\mathrm{NaCl}$ induced changes in ionically bound peroxidase activity in roots of rice seedlings, Plant Soil 216 (1999) 147-153.

[8] J.M. MacAdam, R.E. Sharp, C.J. Nelson, Peroxidase activity in the leaf elongation zone of tall fescue. II. Spatial distribution of apoplastic peroxidase activity in genotypes differing in length of elongation zone, Plant Physiol. 99 (1992) 879-885.

[9] X. Zheng, R.B. van Huystee, Peroxidase-regulated elongation of segments from peanut hypocotyls, Plant Sci. 81 (1992) 47-56.

[10] R.A. Creelman, Abscisic acid physiology and biosynthesis in higher plants, Physiol. Plant 75 (1989) 131-136.

[11] P.-E. Pilet, D.W Barlow, The role of abscisic acid in root growth and gravireaction: A critical review, Plant Growth Regul. 6 (1987) 217-265.

[12] I.N. Saab, R.E. Sharp, J. Pritchard, G.S. Voetberg, Increased endogenous abscisic acid maintains primary root growth and inhibits shoot growth of maize seedlings at low water potentials, Plant Physiol. 93 (1990) 1329-1336.

[13] R.E. Sharp, Y. Wu, G.S. Voetberg, I.N. Saab, M.E. Lenoble, Confirmation that abscisic acid accumulation is required for maize primary root elongation at low water potentials, J. Exp. Bot. 45 (1994) 1743-1751.

[14] G. Zocchi, P. De Nisi, Physiological and biochemical mechanisms involved in the response to abscisic acid in maize coleoptiles, Plant Cell Physiol. 37 (1996) 840-846.

[15] F.Y. Tsai, C.C. Lin, C.H. Kao, A comparative study of the effects of abscisic acid and methyl jasmonate on seedling growth of rice, Plant Growth Regul. 21 (1997) 37-42.

[16] P. Schopfer, Hydrogen peroxide-mediation cell-wall stiffening in vitro in maize coleoptiles, Planta 199 (1996) 43-49.

[17] P. Schopfer, Histochemical demonstrations and localization of $\mathrm{H} 2 \mathrm{O} 2$ in organs of higher plants by tissue printing on nitrocellulose paper, Plant Physiol. 104 (1994) 1269-1275.

[18] E.F. Elstner, A. Heupel, Formation of hydrogen peroxide by isolated cell walls from horseradish (Armoracia lapathifolia Gilib), Planta 193 (1976) 283-289.

[19] D.J. Bradley, P. Kjellbom, C.J. Lamb, Elicitor- and wound-induced oxidative cross-linking of a proline-rich plant cell wall protein: a novel, rapid defense response, Cell 70 (1992) 21-30.

[20] M. Kato, S. Shimizu, Chlorophyll metabolism in higher plants. VII. Chlorophyll degradation in senescing tobacco leaves; phenolic-dependent peroxidative degradation, Can. J. Bot. 65 (1987) 729-735.

[21] M. Sanchez, M.J. Pena, G. Revilla, I. Zarra, Changes in dehydrodiferulic acids and peroxidase activity against ferulic acid associated with cell walls during growth of Pinus pinaster hypocotyl, Plant Physiol. 111 (1996) 941946.

[22] A. Ishida, K. Ookubo, K. Ono, Formation of hydrogen peroxide by NAD (P) $\mathrm{H}$ oxidation with isolated cell wall-associated peroxidase from cultured liverwort cells, Morchantia polymorpha L, Plant Cell Physiol. 28 (1987) 723-726. 
[23] B.I. Naik, R.G. Goswami, S.K. Srivastawa, A rapid and sensitive colorimetric assay of amine oxidase, Anal. Biochem. 111 (1981) 146-148.

[24] S. Jana, M.A. Choudhuri, Glycolate metabolism of three submerged aquatic angiosperms during aging, Aquat. Bot. 12 (1981) 345-354.

[25] L.S. Bates, R.P. Waldren, I.D. Teare, Rapid determination of free proline for water stress studies, Plant Soil 39 (1973) 205-207.

[26] C.C. Lin, C.H. Kao, Disturbed ammonium assimilation is associated with inhibition of roots in rice seedlings caused by $\mathrm{NaCl}$, Plant Growth Regul. 18 (1996) 233238.

[27] C.T. Chen, C.H. Kao, Senescence of rice leaves XXX. Levels of endogenous polyamines and dark-induced senescence of rice leaves, Plant Cell Physiol. 32 (1991) 934-941.

[28] Y. Kato, D.J. Nevin, Isolation and identification of O-(5-O-feruloyl- $\alpha$ - L-arabinofuranosyl)-(1-3)-O- $\beta$-Dxylopiranosyl-(1-4)-D-xylopyranose as a component of Zea shoot cell walls, Carbohydr. Res. 154 (1985) 177187.
[29] R.D. Hartley, W.H. Morrison, D.S. Himmelsbach, W.S. Borneman, Cross-linking of cell wall phenolic arabinoxylans in graminaceous plants, Phytochemistry 29 (1990) 3705-3709.

[30] L.-M. Chen, C.C. Lin, C.H. Kao, Copper toxicity in rice seedlings: changes in antioxidative enzyme activities, $\mathrm{H}_{2} \mathrm{O}_{2}$ level, and cell wall peroxidase activity in roots, Bot. Bull. Acad. Sin. 41 (2000) 99-103.

[31] G.G. Gross, Cell wall-bound malate dehydrogenase from horseradish, Phytochemistry 16 (1977) 319-321.

[32] T.A. Smith, Di- and polyamine oxidases of higher plants, Biochem. Soc. Trans. 13 (1985) 319-322.

[33] R. Angelini, R. Federico, Histochemical evidence of polyamine oxidation and hydrogen peroxide production in the cell wall, J. Plant Physiol. 135 (1989) 212-217.

[34] R.I. Haynes, K.M. Goh, Ammonium and nitrate nutrition of plants, Biol. Rev. 53 (1978) 465-510.

[35] G. Frahry, P. Schopfer, Hydrogen peroxidase production by roots and its stimulation by exogenous NADH, Physiol. Plant 103 (1988) 395-404.

[36] A.C. Allan, R. Fluhr, Two distinct sources of elicited reactive oxygen species in tobacco epidermal cells, Plant Cell 9 (1997) 1559-1572. 